\title{
In conversation with Elliot Philipp
}

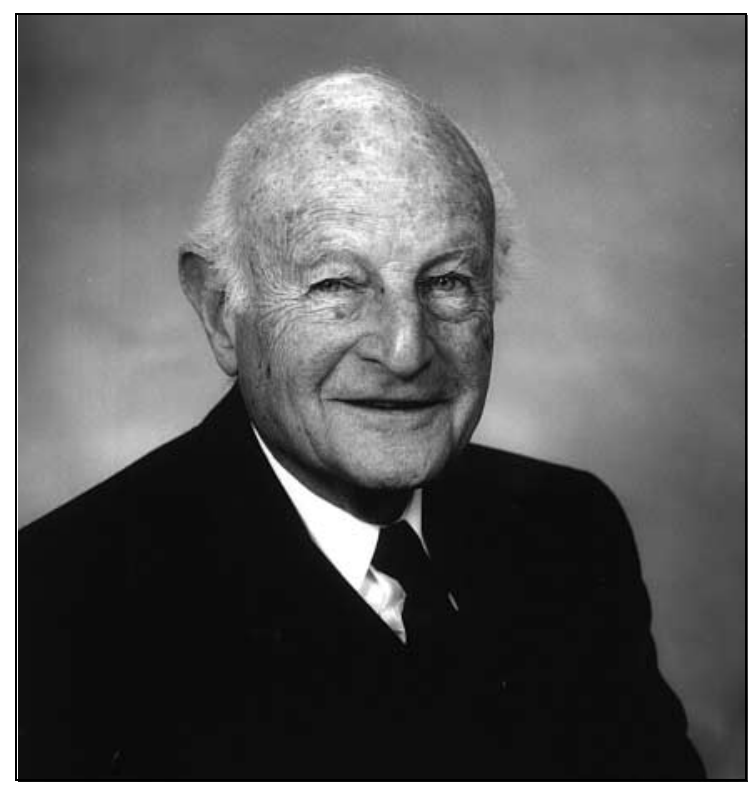

Elliot Philipp

When Hugh Freeman heard of Elliot Philipp's connection with the Freud family he invited him to be interviewed for the Psychiatric Bulletin. Elliot Philipp's own background as a doctor is very definitely not in psychiatry, although during Second World War service in the Royal Air Force he did become very interested in the psychological effects of flying stress in air crew and even took out membership of the Section of Psychiatry in the Royal Society of Medicine. Gynaecology has, however, since the war been his speciality and all his postgraduate training and practice has been in gynaecology, obstetrics and surgery. Elliot Philipp met the great Sigmund Freud himself and even after Freud's death, continued to be invited to family gatherings in their home at 20 Maresfield Gardens, which has since become the Freud Museum.

Could you explain your relationship with the Freud family?

My grandfather, Elias Philipp, was born in 1821. His younger sister was Emmeline, who married Berman Bernays, the son of the Chief Rabbi of Hamburg. He died young, when his three children were in their teens; they were Eli, Minna and Martha, Freud's future wife. As they were all under 21, my grandfather was then nominated as their guardian. Emmeline moved to live near her brother, so that they all became like members of one family. My own father was born in 1887, so that he was much younger than the Bernays children, and Martha was like an extra mother to him.
My father told me that his own father disapproved strongly of Freud as a prospective husband for Martha, and said that no ward of his was going to marry a man who had no prospects and no religion. As a result, he held up their engagement for at least two years. Meanwhile, Minna had not married because her fiancé had developed tuberculosis, so she came along with Martha when her sister moved to Vienna. Their brother emigrated to New York, where his son, Edward, was a founder of the public relations profession.

\section{How did you first encounter them?}

In 1935, when I was an undergraduate at Cambridge, my father thought that I ought to make contact with the family, because of our connection with them, and sent me out to Austria. I went by train to Vienna, where I was met by another cousin, Hella Bernays, and was taken to Grinsing, outside the city; I stayed there for a few days with the Freuds. They rented a house there for each summer from 1934 to 1937.

\section{Can you tell me what the house in Grinsing was like?}

It was quite large, with room for guests, and was rather like a Georgian house, very symmetrically designed with a big, pleasant garden. It was very quiet, because it was then out in the countryside. Grinsing is famous for its wine; there are vineyards around and a wine festival every year. When I went there, though, the grapes had not yet been picked.

What it was like when you first met Freud's wife Martha and her sister, Minna?

They were very very welcoming. Martha was grey-haired, small and slightly bent. She was very maternal and obviously a good housewife. Minna was very upright and looked severe with her pince-nez. I thought she seemed a little 'school-marmy'. Mrs Freud was a lovely, maternal lady. She said, "Have some coffee", and then she introduced me to Freud, who came down from upstairs. He did all his writing in the summer on a terrace, where he had a small table, overlooking the garden. He always had a 'chow-dog' beside him. When they moved to London, his son, Ernst, installed a similar terrace at Maresfield Gardens. When I was introduced to him, he said straightaway, "Oh, I know your father . . . is he still so Orthodox?"

\section{Why did he ask that?}

I think they'd previously had vigorous discussions. There's quite a lot in the literature about Freud's correspondence with Martha, explaining her grandfather's religiosity as a 


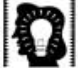

special articles kind of myth! Then he said, "Your father should read my book, The Future of an Illusion"! Before I left England, my father, who was quite a shrewd man, had said to me "He'll tell you that; he's a good publicist, so just say, "He's read it, and it's strengthened his faith, rather than otherwise". In 1939, my father was very angry when Freud's book Moses and Monotheism came out, because he felt that this was false scholarship and mostly invention. I don't think he ever told Freud that!

I think a lot of people were angry about that book. Was your impression that, in financial and economic terms, the Freud family were quite well off?

I think they were. They certainly didn't want for anything. At Grinsing, the house was very comfortable. They had maids, as all upper middle-class families did at that time. I don't think they had a car. I can't remember them having one in the country. I imagine that some patients must have got out to see him there, but I'm not certain about that. It was the summer vacation for him, which was the time he set aside for writing, but I have a feeling that occasional patients would come there and get an hour of analysis.

\section{Did he speak to you in German or in English?}

I think in German. He was a polite man, but his speech was a little indistinct, due to the cancer of the mouth.

\section{What happened when you talked to Martha?}

We walked in the garden and discussed religion in relation to why Hitler behaved like he did. The storm clouds were gathering, and she said, "There are people who don't realise that there's a God in heaven, who will in the end get his way".

But as far as Freud was concerned, she'd had a very traumatic experience with him.

\section{What was that?}

On the first Friday night after they were married, she got candles out and lit them - as was the Jewish custom because she'd been brought up in quite an Orthodox way. Certainly, her grandfather had been very Orthodox indeed. But Freud made her put the candles out; this niggled at her the whole of her life. When they finally came to London, she still had the candlesticks and the velvet cloth that one puts over the bread, for a Friday night service. My mother was given the velvet cloth. Martha Freud said to her, "Since you keep the Sabbath, and I've even brought the cloth to England, you have it".

So all these years, she had really resented Freud's action?

Yes. She'd resented his interference in her religious observance. She had been strongly influenced by her grandfather, Chief Rabbi Bernays. She told me more than once that the only thing that rankled in their marriage was the fact that he'd made her put the candles out on the Sabbath. That really upset her, for the whole of her life! She also told me that Freud was a very good businessman.

\section{Did Freud give you a present before you left Vienna?}

Yes. He gave me his signature. He said "Here is my signature. It's going to be valuable one day". He put it in a little leather wallet and I've still got it.

\section{What about the Freud sons?}

When they came to England, my father helped the third son, Ernst, find a house for his parents in Elsworthy Road. When Freud himself came over here, he first stayed in a hotel in Maida Vale for a few days, while that house was made ready, and then remained there for two months, until the house in Maresfield Gardens was converted for them. It was a very big house - now the Freud Museum. I was in and out of there quite a lot, even before I began to be given lessons by Freud. Martha, his wife, was very very fond of my father and also seemed to be quite fond of me. She would invite me around from time to time; I think they accepted me as a member of the family. I had contact with Ernst, his youngest son, a lot. He was an architect in London, and actually redesigned our home. I was also very fond of Martin. I had a cottage in the country, even though I was only a medical student then, and he came down and stayed there. In fact, the bookshelves in my cottage were built by Martin!

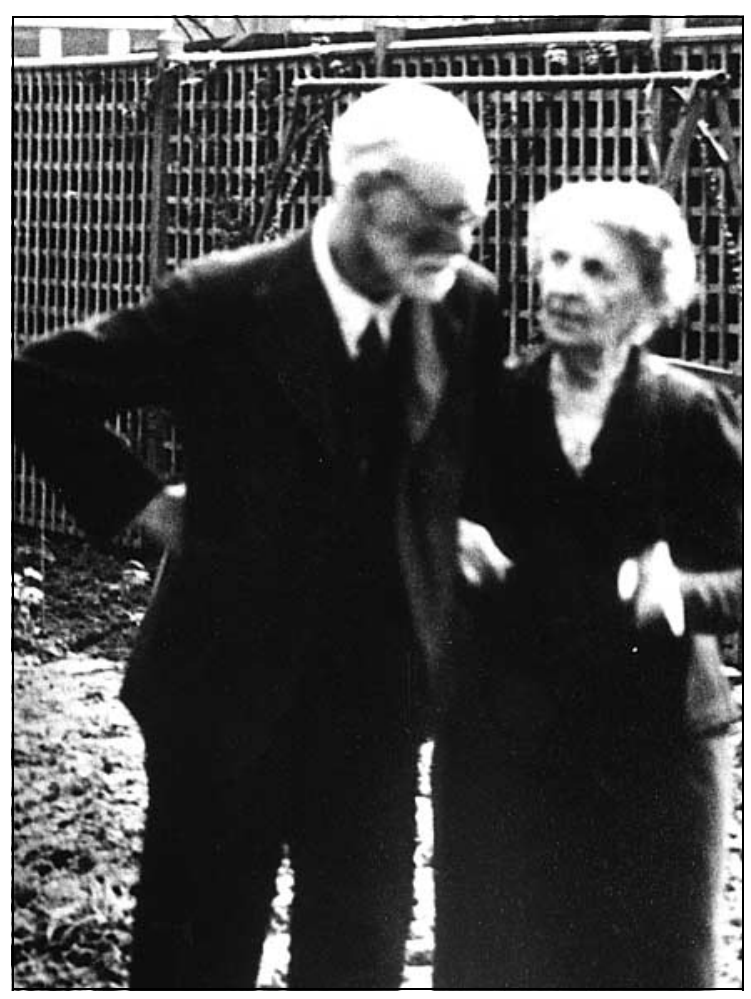

Sigmund and Martha Freud, taken in their garden, London 
Your further contact with Freud was as a result of a book?

Yes, I had read several for the lay public, as well as several more serious ones on sexual relationships. I said to two friends of mine, "I think I could do better than that". They laughed and said, "You can't". However, I sat up day and night for several days and did produce a book. I sent it to Gollancz; they said they already had another book on the subject which was commissioned, but mine was worth publishing and I should go to another firm. I looked around and sent it to a small firm called the Wales Publishing Company. Within a week or two, they said "Come and see us", and they took it on. Then I got worried. I'd copied the anatomy from Gray's Anatomy, which of course is not living anatomy, and I got a friend, Kenneth Snowman, to do the drawings. I didn't know whether there were a lot of mistakes in it. So I spoke to my father, who said "Well, you'd better show it to a doctor". But I said, "I don't know any doctor who could look at a book like that". "Oh", he said, "Sigmund's not that busy . . . I'll see what Martha has to say". So here was a medical student, who wasn't qualified and wasn't married, being taught by Sigmund Freud. He read it and told Martha he wanted to see me and that he would want to spend quite a long time on it. At that time, he was sometimes rather lonely. He could sometimes be very difficult or even tyrannical, and his children and grandchildren were busy making their way in England.

\section{What happened when you went to see him about it?}

Martha said, "He wants to see you, and he will spend some time with you. He'll keep you for the best part of an hour, because nobody ever goes into that study without staying an hour, but he may interrupt once or twice to wash his mouth out, because he's got this terrible cancer". Anyhow, after about 50 minutes, he said, "Go". As I came out, Martha said, "Stay and have a cup of tea or coffee, and he'll join us". And he did; it was very sociable and relaxed then. The interviewing with him had been a little tense, because - I don't know why he insisted on talking to me in German, and I didn't easily understand everything he had to say. But he was an incredibly wise man.

\section{In this first interview with him about your book, did he} make any particular comments?

The book starts with anatomy, physiology and then psychology, so he went through the chapter on psychology, very thoroughly, line by line. It was quite obvious that I knew no psychology. But he elaborated a lot on the basic ideas that l'd got that human relationships were important, and that couples had to have faith in one another. He said "I'll continue on another occasion to tell you about bisexuality and the Oedipus complex", which of course I knew nothing of at that time. At the first visit, he told me to read all about Helen of Troy, and he said, "You really must read that ... whatever you can put your hands on, because that is the greatest demonstration of love. It was a 10-year war waged because somebody loved somebody else, and wars are fought partly because people love and hate one another". He said that Helen must have had an unbelievably strong sexual attraction. He told me to show him the book again when I had corrected the chapter on psychology.

\section{How many of these sessions did you have?}

It must have been somewhere about half a dozen, maybe more. Freud seemed to have an inbuilt clock which told him when 50-55 minutes had passed.

\section{Do you remember any of the other topics that he} discussed with you?

He explained the development of sexual maturity through the stages of mother love, the Oedipus complex, the later attachment to the father - the homosexual phase. He also discussed bisexuality, sexual awareness and masturbation.

\section{What was his view about that?}

He said it was a form of release of sexual tension. He certainly didn't go along with the Church's condemnation. I'm quite sure he never told his children not to handle their penises or anything like that. He talked about the essential femininity that was to be found in every man and the masculinity in every woman, mentioning men having nipples and women a clitoris. He said you'd carry that all your life. He certainly did not in any way condemn people who practised homosexuality. It wasn't a subject openly discussed then as it is today, but he was one of the people who brought it to the fore.

What was your impression of the study in Maresfield Gardens?

The study was as it still is today in the museum. It's a big room, but in a way, it's warm and cosy, certainly when the heating was on. As you came into the room, he had his desk slightly nearer the far wall. People being interviewed by him or talking to him sat on the far side and he sat in his usual chair, on the other side of the desk. We talked through a kind of tunnel of antiquities. They were absolutely tidily piled all over the desk, and in the cupboards behind, and on the shelves everywhere. He told me quite a lot about them, but one wall was full of marvellous books. He was a very, very literate man, not only in psychiatry or psychology, but in Shakespeare, Goethe and all the classics.

\section{Were there any works of art in the rest of the} house?

Not on the staircase, but that had framed honorary degrees. He was very proud of them particularly of being made a Fellow of the Royal Society.

But he was unable to go to the presentation, I think. 
No. He was too ill. They came to him and a small ceremony took place in the garden.

special articles
Did he say anything to you about relationships between doctors and patients?

Yes. He didn't approve of free treatment. He thought patients should all pay, because the actual physical handing over of money was part of the treatment. And they should pay at the end of an interview, or a consultation, not at the beginning. He was very adamant about it. When I protested that there were poor people who couldn't pay, he had no answer.

\section{At this time, he had taken on quite a few pupils?}

Yes. After his death, the family found a diary with his appointments and earnings. He earned 80 guineas in one week, so he must have seen 20 pupils in that time, at four guineas a session. I never came across any of the others.

\section{That was a very large sum of money at that time?}

It was. And that was when he wasn't analysing them. He wasn't taking on new patients for analysis. I think my father may not have paid for my lessons, because he had helped the family a lot when they came to England, but he certainly sent a box of very good cigars. We have still got the letter from Freud, thanking my father for them. Of course, at this time, he was relying enormously on his daughter Anna.

\section{How did she strike you?}

She was a splendid woman, really lovely, gentle and soft, but very, very determined. It was quite clear that she was his heir, although she was the youngest of his six children; he was very fond of her, and so was his wife. I think Martha realised that Anna had a better brain than anybody else in the family.

Did Freud say anything about his rivals and the people who parted company with him?

I made him very angry, about that. I mentioned Adler one time, and he really was very dismissive. When I mentioned
Jung, he just didn't answer at all; there was a hiatus in the conversation. But he really hated Adler.

\section{Were there any other things that annoyed him in your} interviews?

Yes. He watched my face very carefully and would come out with a long term, maybe an endocrinological one, and I wouldn't know what he was talking about, although I had done some endocrinology by this stage. He would say, "Do you understand?" I would say "Yes", and he would reply "Well, you don't, so don't say 'Yes'!" He'd then try and explain it. I didn't find him a loveable man, because I thought there was a streak of cruelty in him. However, he made one particular joke. I said in all innocence, because I really didn't know, "How long does intercourse last, or how long should you take over it?" He just looked at me and said "Elliot, don't marry a woman. Marry a cuckoo clock"!

\section{What about psychoanalysis for yourself?}

He'd been talking about the role of psychoanalysis, and I said, "Do you think I should be in analysis?" he said "Elliot, have pity on the analyst!"

\section{Anything else you particularly remember?}

Yes. I was familiar enough to be able to say to him "How is it you manage to look so smart and tidy all the time?" He said, "It's very, very important - a doctor must look smart and tidy. Patients don't have such confidence in people who dress sloppily. You must dress tidily, especially if you're going to be a gynaecologist".

\section{What was his opinion of your book in general?}

I asked "Should it be published?" and he said "Well, yes, it's a lightweight, but it will sell, it will sell".

And he was right...

Oh yes, he was right! 